\title{
Katoava mordvalainen identiteetti - karatait ja Saratovin alueen ersäläiset
}

Kirjoitus pohjautuu professori Klara Jevgenjevna Maitinskajan syntymän 100-vuotismuistosymposiumissa Moskovassa 12.-17.11.2007 pidettyyn esitelmään.

Sain Jenny ja Antti Wihurin rahastolta jo vuonna 2001 matka-apurahan, jonka pystyin käyttämään vasta vuonna 2006. Sen turvin kävin yhdessä ersäläisen folkloristin Vasili Petrovitš Beljakovin kanssa sekä Tatarstanissa karataimordvalaisten luona että Saratovin alueella samoissa ersämordvalaiskylissä kuin akateemikko Šahmatov 100 vuotta sitten.

\section{Karataimordvalaiset}

\section{I.I. Tutkimushistoria}

Mordvalaisten pääongelmia on, että heistä peräti $70 \%$ asuu nimikkotasavaltansa Mordvan ulkopuolella ja sielläkin he ovat vähemmistönä ja muodostavat sen asukkaista kolmanneksen. Vuoden 2002 koko Venäjää koskevan väestönlaskennan mukaan mordvalaisten lukumäärä on laskenut huomattavasti vain n. 843000 henkeen. Tilastot osoittavat mordvalaisten vähentyneen Mordvassa n. 10\% ja naapurialueilla 20-30\% verrattuna edellisen, vuoden 1989 väestönlaskennan tuloksiin (FUW 2004: 8-9; Feoktistov \& Saarinen 2005: 387).

Karataimordvalaisia ei enää lasketa mukaan Tatarstanin mordvalaisiin, joita oli vuonna 2002 vielä 23700 (eli 2,8 \% kaikista mordvalaisista), sillä he eivät ole puhuneet mordvaa enää ainakaan yli sataan vuoteen. Karataimordvalaisia on käyty useasti tutkimassa ja tuloksia on julkaistu tieteellisessä kirjallisuudessa alkaen Strasburgissa lääketieteestä väitelleen akateemikko Ivan Ivanovitš Lepjohinin (1740-1802) päiväkirjoista vuosilta 1768 ja 1769 (ilmestyneet Pietarissa 1771). Lepjohin johti Venäjän akatemian tutkimusmatkoja Keski-Venäjälle, Uralille ja Pohjois-Venäjälle vuosina 1768-1772. Hänen mukaansa mordvalaiset voidaan jakaa kolmeen (tai peräti neljään) haaraan: ersäläisiin, mokšalaisiin (коренные или высокїе мокиане, простые мокшане) ja karataihin (Lepjohin 1771: 155). Erotteluperusteitaan hän ei paljasta lukijoille. Karataiden hän kertoo asuvan kolmessa Kazanin kihlakunnan (eli ujestin) kylässä. Aivan ensimmäiset maininnat karataista sisältyvät kyllä jo D. Pušetšnikovin ja A. Kostjajevin kirjaan Книги письма и мюрры (painettu 1624-1626) sekä käsin kirjoitettuun vuoteen 1692 ajoitettuun kirjurin laatimaan luontoisveroluetteloon, jossa mainitaan kahdesti Karatain kylä ja kahdesti Korotain, neljästi Mensitovin asutus ja kahdesti Melsitovin. Historiallisissa asiakirjoissa niiden asukkaat mainitaan mordva- 
laisina. (Ahlqvist 1858: 261; S. Melnikov 1859: 147-151; P. Melnikov 1867 [1981]: 21; Paasonen 1903a: 9-10; Dokumenty 1940: 91-93; Mokšin 1977: 109-115; 1993: 66-77; 2001a; 2001b; 2007a; 2007b.)

Lepjohinin jälkeen on karataiden etnisestä alkuperästä ilmaantunut muitakin mielipiteitä. Jotkut tiedemiehet pitivät heitä kristittyinä tataareina, kuten mm. ensimmäinen heidän luonaan vieraillut suomalainen fennougristi August Ahlqvist (18261889). Hän tutki karataimordvalaisia noin 80 virstan $(1$ virsta $=1,06 \mathrm{~km})$ päässä Kazanista Bogorodskojen volostissa Volgan oikealla rannalla neljä päivää maaliskuussa 1858. Tuolloin Mordovskije Karataissa asui 500 sielua (eli miestä) ja seitsemän virstan päässä Mensitovassa 143 sielua. Miesten hän kertoo osaavan hyvin venäjää, mutta naisten vain tataaria, vaatetukseltaan he olivat mordvalaisia (Ahlqvist 1858: 263-264; 1861: VII). Kuolleiden muistojuhlaa kuvaavassa lehtiartikkelissa vuodelta 1862 mainitaan Mordovskije Karatain asukkaiden olleen tataaria puhuvia mordvalaisia (S. Melnikov 1862: 89). Seuraava heidän luonaan käynyt suomalainen oli kansatieteilijä Axel Olai Heikel (1851-1924), joka vieraili ainakin Mensitovassa kesällä 1884 Volgan seudulle suuntautuneen tutkimusmatkansa aikana (Niiranen 1987: 40). Hän katsoi karataiden puvun todistavan heidän mordvalaisperäisyyttään ja julkaisikin niistä kaksi matkakumppaninsa Agathon Reinholmin (1857-1887) tekemää piirrosta (Heikel 1899: IV-V, taulut LXXXII ja LXXXIII).

Kolmas suomalainen, Heikki Paasonen (1865-1919) vieraili karataiden luona Volgan läntisellä rannalla Tetjušin kihlakunnassa kaksi ja puoli päivää elokuussa 1901 (Paasonen 1903b: 19-20). Hän oli ensimmäinen, joka ratkaisi heidän alkuperänsä ongelman artikkelissaan Die sogenannten Karataj-Mordwinen oder Karatajen (Paasonen 1903a). Karataiden puhuman tataarin murteen foneettisen ja leksikaalisen analyysin sekä historiallisen ja etnografisen aineiston pohjalta Paasonen arveli heidän olleen paikallisia mordvalaisia, jotka elivät läheisessä vuorovaikutuksessa tataarien kanssa. Hän oletti heidän puhuneen mordvaa 1600-luvulla ja säilyttäneen kaksikielisyyden pitkään (Paasonen 1903a: 49-51).

Karataiden sanaston vertaamista mordvan kieliin ja varsinaiseen tataariin on jatkettu pienin edistysaskelin, kuten on tehnyt mokšalainen lingvisti Aleksandr Pavlovitš Feoktistov (1928-2004), joka kävi keräämässä sanastoa Mordovskije Karataissa vuonna 1956. Pieni sanasto on julkaistu osana isompaa mordvalais-turkkilaisten kontaktien kysymyksiä käsittelevää artikkelia (Feoktistov 1965: 338-341). Viimeisin on tataarilainen Darija Bairamovna Ramazanova, joka arvelee karataimordvalaismiesten avioituneen tataarilaisten naisten kanssa, sillä avioliiton kautta tulleista sukulaisista ja vaimon sisaruksista käytetään tataarilaisia nimityksiä, sen sijaan aviomiehen sisaruksista käytetään mordvalaisperäisiä. Verisukulaisten nimityksissä mordvalaiset, venäläiset ja turkkilaisperäiset termit ovat kietoutuneet yhteen. Karataiden kielen sukulaisuustermeissä hän näkee kahden alasysteemin yhteentörmäyksen. Samanlainen ilmiö löytyy myös joistakin tšuvassien ja baškiirien ryhmistä sekä vähäisemmässä määrin kazaheilta ja jakuuteilta (Ramazanova 2000: 260).

Ersäläinen tiedemies Makar Jevsevjevitš Jevsevjev (1864-1931) arveli tataarien siirrättäneen mokšamordvalaisia Kazanin kaanikunnan aikana kaanin maita viljele- 
mään Kazanin ympäristöön. Kaanikunnan kukistuttua vuonna 1552 valtaosa heistä palasi takaisin vanhoille asuinsijoilleen. Ne, jotka jäivät uusille asuinsijoilleen, joutuivat kokemaan voimakkaan tataarilaisen kulttuurin vaikutuksen ja tulivat tunnetuiksi karataimordvalaisina (Arslanov 2000: $26^{1}$ ).

Tatarstanin alueella etninen jako menee yleensä niin, että mokšalaiset asuvat Volgan oikealla rannalla ja ersäläiset vasemmalla (Jevsevjev 1966: 385, 392). Arkeologit ovat löytäneet Volgan vasemmalta rannalta 1500-luvun mordvalaishautoja Laiševon $^{2}$ rajonin (eli piirin) Taškirmenin kylästä. Korujen ja aseiden perusteella hautoja on syytä pitää mordvalaisina, mutta väestö on tataarilaistunut jo varhain (Halikov 1965: 164-166). Muualtakin bolgaarivaltion alueelta löytyy todisteita erityisesti mordvalaisten tulosta sinne, kuten hautakirjoituksia, joihin sisältyy etnonyymi mokša. 1300-luvulta alkaen tunnetaan mordvalaisten - karataiden esi-isien - asuttamia kyliä (Zelenejev 1999: 23-24). Karatait pitävät myös itse alkukotinaan bolgaarivaltioon kuuluneita Volgan-takaisia alueita ja ovat säilyttäneet kertomuksia muuttamisestaan Volgan vasemmalta rannalta sen oikealle rannalle (Belitser 1960: 254).

Luultavasti vain yksi kirja - Kazanissa ilmestynyt - on kokonaan omistettu karataimordvalaisille: Мордва-каратаи: язык и фольклор (Ramazanova 1991), muuten tiedot heistä täytyy poimia eri tahoilla julkaistuista artikkeleista. Pukututkija, etnografi Vera Nikolajevna Belitser (1903-1983) vahvistaa tutkimuksessaan, että antropologisesti karatait ovat lähempänä mordvalaisia kuin tataareja, kulttuurisesti he ovat saaneet vaikutteita monelta taholta. Hän johti Neuvostoliiton tiedeakatemian ja Mordvan tieteellisen tutkimusinstituutin järjestämiä etnografisia tutkimusmatkoja karataiden luokse vuosina 1956 ja 1958 . Tuolloin karataita hänen arvionsa mukaan oli jäljellä tuhatkunta ${ }^{3}$ (Belitser 1960: 227-231, 255; Mokšin 1993: 161-165).

Tataarilainen professori Leonid Šaisultanovitš Arslanov on vuosikymmenien ajan, kandidaatinväitöskirjastaan ${ }^{4}$ lähtien tutkinut karataiden kieltä ja havainnut siinä olevan toisaalta piirteitä, jotka yhdistyvät Mordvassa ja Penzan alueella puhuttuihin mišääritataarin murteisiin, mutta myös sellaisia elementtejä, jotka ovat arkaaisempia eivätkä tyypillisiä noille murteille (Arslanov 1965, 1991a, 1991b, 2000). Toisaalta heidän kielessään näkyy vain niukalti piirteitä ympäröivien Tatarstanin tataarilaiskylien keskimurteista. Todennäköisesti tämä todistaa heidän omaksuneen turkkilaisen kielen varhain, viimeistään 1500-luvulla, ja jossain muualla kuin heidän nykyisellä asuinalueellaan. Mordvalaisen professorin Mosinin juhlakirjassa Arslanov jopa sijoit-

\footnotetext{
1 Mainintaa karataista ei kuitenkaan löydy Jevsevjevin kootuista teoksista vuodelta 1966, vaikka artikkeli ilmoitetaankin julkaistun siinä uudelleen.

2 Ilmeisestä mordvalaisperäisyydestään huolimatta - lajšsems 'itkeä kuolinitkuja' - samannimisen historiallisen volostin 296 kylässä ei tilastojen mukaan 1800-luvun jälkipuoliskolla enää asunut mordvalaisia, vaan venäläisiä n. 81 000, tataareja n. 54200 ja 3 udmurttia (Vetšeslav 1869: 16; 1875: 306-307). Sen sijaan seudun kristittyjen tataarien vanhanaikainen puku voisi hyvinkin olla mordvalaisperäinen (Paasonen 1903a: 46 viitteineen).

3 Muihin lähteisiin vertaamalla voi päätellä Belitserin arvion liian suureksi.

4 Feoktistov (1965: 339) kiittää Arslanovia tämän hänen käyttöönsä antamasta käsikirjoituksesta. Se valmistui Kazanissa vuonna 1966 nimellä Татарские говоры правобережных районов Татарской и Чувашской АССР.
} 
taa karataiden migraation lähtöpaikan Mordvan Tenguševin piirin Melsetjevon kylään (ersäksi Mel'ćidvel'e) Šokšajoen ja Jeremšajoen väliselle alueelle (Arslanov 2000: 28). Lähteenä hänellä on Inževatovin toponyyminen sanakirja (Inževatov 1987: 137), josta ilmenee myös, että mordvalaisilla on käytössä samaa kantaa olevat sukunimet Melsitov ja Melsetjev. (Taustalla on esikristillinen mordvalainen miehennimi Mel'can tai Mel'capa.) Tätä tukee hyvin se seikka, että kuulin Zaovražnyje Karataissa asuvien karataiden puhuvan entisestä kotikylästään sekä Mensitovona että Melsitovona (ks. lisää luvusta 1.2). Tämä nimen kahtalaisuus on vanhaa perua, ja se käy ilmi vanhoista lähteistä kenenkään kuitenkaan ilmiötä kommentoimatta (S. Melnikov 1859: 147-151; Paasonen 1903a: 17; Dokumenty 1940: 91-93). Satakunta vuotta sitten tämän kylän nimi paikallisella kielellä oli Mäste (Paasonen 1903a: 12).

Lepjohin ja monet muut lähteet - vieläpä hyvin uudetkin (mm. Mokšin 1993: 68; 2001a) - kertovat karataiden asuvan kolmessa kylässä, jotka nykyään kuuluvat pieneen ja köyhään Kamsko-Ustjinskin rajoniin. Tutkimusmatkani aikana kuitenkin osoittautui, ettei tilanne ollut enää niin. Joka tapauksessa äänitin viimeisiä karataita ja valokuvasin noita kolmea kylää: Mordovskije Karataita, Zaovražnyje Karataita (< Mensitovo) ja Šeršalania. Viimeiset karatait ovat ortodokseja, ja heidän kielessään on edelleen kuultavissa joitakin piirteitä siihen sulautuneesta mordvasta ja joistakin kaukaisista, osin jo kadonneista tataarin murteista. Kyläläiset sanoivat ulkopuolisten aina naureskelevan heille heidän puhuessaan äidinkieltään (eli mišääritataarin paikallista murretta) tai venäjää. Paasosen aikaan aviopuolisoita muisteltiin etsiskellyn muista karataikylistä sekä etenkin saman Tetjušin ujestin eteläisestä, nyt jo tataarilaistuneesta mokšalaiskylästä Urjumista ${ }^{5}$ sekä Volgan toiselta puolelta Spasskin kihlakunnan ersäläiskylistä. ${ }^{6}$ Suhteet tataareihin eivät olleet mitenkään erityisen läheiset ilmeisesti eri uskonnosta johtuen. Silti ympäristön tataarilaistava vaikutus tunkeutui näihin varmaan aluksi melko puhtaasti mordvalaisiin kyliin. Aiemmin tataarilaiset ja venäläiset puolisot olivat harvinaisia. Nyt seka-avioliitot etenkin venäläisten kanssa ovat tavallisia, kuten itse saatoin huomata.

Etnonyymia karatai eivät karatait ole vanhastaan itsestään käyttäneet, vaan sanovat venäjäksi olevansa mordvalaisia. Näin oli tilanne vielä 1976 (Mokšin 1977: 114). Sana on kyllä hyvin tunnettu, ja jossain määrin he ovat nyt alkaneet nimittää siten itseäänkin puhuessaan venäjää. Lähistön venäläiset kutsuvat heitä mordvalaisiksi. Tataarit tuntevat heidät samalla nimellä kuin muutkin mordvalaiset, sg. muqšâ, pl. muqšâlar, jota nimitystä karatait myös käyttävät itsestään tataaria puhuessaan (Paasonen 1903a: 14, 39; Filippov 1913: 356; Mokšin 1993: 68). Tämä etnonyymi on vanhoissa historiankirjoissa melko tavallinen tarkoittamassa toisinaan myös kaikkia

5 Kylä oli alun perin tšuvassilainen, mutta 1600-luvun lopulla sinne muutti mordvalaisia (Mokšin 1989: 76). Vaimojen haku lienee katkennut jolloinkin 1800-luvun alkupuolella, koska Jevsevjevin tiedustellessa asiaa kyläläiset muistelivat viimeisen sieltä tuodun vaimon kuolleen 70 vuotta sitten (Mokšin 1989: 113).

6 Kaikkiaan Kazanin kuvernementista löytyi 1800-luvun lopulla varsin vähän mordvalaisia: Tšistopolskin kihlakunnasta 6157, Spasskin kihlakunnasta 9202 ja Tetjušin kihlakunnasta 4605 henkeä (Vetšeslav 1875: 268-269, 310-311, 372-373). 
mordvalaisia. Ersäläiset mainitaan harvemmin, ja välillä heidät rinnastetaan mordvalaisiin (eli mokšalaisiin) (Safargalijev 1965: 224).

Paikannimi Karatai lienee tataarilaista alkuperää, ja sitä on toisinaan pidetty maantieteellisenä, toisinaan etnisenä nimenä; monilla turkkilaiskansoilla se on tunnettu heimonimenä (Belitser 1960: 228 viitteineen). Hydronyymialkuperää puoltaisi Mordovskije Karatain läpi virtaava Karatai-joki (Mokšin 1989: 64-65). Paasonen ehdottaa selitykseksi qara 'musta' + taj 'varsa' aikaisempien tutkijoiden ${ }^{7}$ mielipiteestä poiketen (Paasonen 1903a: 41), ja tämä selitys on hyväksytty etymologisiin lähteisiin (Vasmer 1967: 194). ${ }^{8}$

\section{I.2. Kylien historia, asukasmäärä ja nykytilanne}

Vuonna 1869 Kazanissa painettujen tilastojen mukaan ilmoitettiin Mordovskije Karatain kirkonkylän asukasmääräksi 910 ja vuonna 1875 luku oli 930 (Paasonen 1903a: 13; Vetšeslav 1875: 362-363). Hieman aikaisemmat tilastot kertovat vuonna 1859 kylässä olleen taloja 161 ja yksi kirkko. Vuoden 1908 tilastot ilmoittavat siellä asuneen 701 miestä ja 720 naista (Filippov 1913: 355). Paikallisten tietojen mukaan Mordovskije Karatai olisi perustettu 400-450 vuotta ennen Belitserin haastatteluaikaa ja muiden kahden karatailaiskylän asukkaat olisivat sieltä lähtöisin. Joka tapauksessa kirjalliset lähteet todistavat kolmen karatailaiskylän olemassaolosta ainakin jo 1600luvun alussa (Belitser 1960: 229). Vuonna 1958 karataiden lukumäärä tässä kylässä oli laskenut jo alle 300:n (Mokšin 2001: 286). 1950-luvulla kolhoositalouksia laskettiin olevan 140, kylässä oli oma kyläneuvosto ja neliluokkainen venäjänkielinen koulu, joka pian lakkasi toimimasta. Muutto kaupunkeihin työtä etsimään on viime vuosikymmeninä ollut voimakasta. Vuonna 1976 Saranskin yliopiston tutkijaryhmän käydessä tekemässä kielisosiologisia selvityksiä Mordovskije Karataissa oli jäljellä 68 taloutta, Šeršalanissa 24, Zaovražnyje Karataissa 7 ja kylien yhteinen väkimäärä jäi alle 300:n. Lapset kävivät venäjänkielistä koulua Sjukejevon ja Kirelskojen kylissä (Mokšin 1977: 114-115).

Vuonna 2006 Mordovskije Karataissa tai Roždestvenskojessa tai Iskevelessä (< tat. iske 'vanha' + md. vel'e 'kylä'; Belitser 1960: 229) Karataijoen varrella oli 96 asukasta ja 43 taloa. Määrä on siis huimasti pienentynyt puolentoista vuosisadan kuluessa. Siellä on kuitenkin jäljellä vielä 16 lasta, joiden koulumatka vie päivittäin naapurikylään. Mutta koska kylän päätielle yhdistävä tienpätkä on huonokuntoinen - kelirikkoaikaan sitä pitkin voi kulkea vain traktorilla - kuljetusongelmat ovat jatkuvia ja monet nuoret perheet ovat muuttaneet muualle. Keskellä kylää on pieni uusi

\footnotetext{
$7 \mathrm{Mm}$. Rittich arvelee merkityksen olevan 'musta vuori' ja jälkiosan tulevan sanasta tau 'vuori', vrt. tat. tau, osm. dă̆ (Paasonen 1903a: 41 viitteineen).

8 Molemmat muodot, Korotai ja Karatai, ovat sekä sukuniminä että paikanniminä melko tunnettuja, mikä sopii hyvin kuvaamaan venäjän okanje-murteiden heijastumista kirjurien epävarmoina merkintöinä vanhoissa lähteissä. Lisäksi Etelä-Venäjän alueella käytetään lyhyttä kietaistavaa päällystakkia tai hihatonta liiviä, joka tunnetaan venäläisellä nimellä корота́ŭ < коро́ткий 'lyhyt', корота́mь 'lyhentää' (tarkemmin SRNG 14: 367-368); tästä saadaan myös murteellinen merkitys 'ihminen, joka käyttää korotaita'. Myös joidenkin mordvalaisryhmien naiset käyttivät samanlaista vaatekappaletta.
} 
kioski, posti jaetaan eräästä talosta suoraan vanhuksille. Yksi kylän naisista on saanut jonkin verran sairaanhoidon opetusta, ja hänellä on kotonaan lääkkeitä. Kyläläisistä saadaan vielä kokoon juuri ja juuri kansanperinneyhtye nimeltään Mordovskije uzory, jonka johtajana toimii entinen klubin johtaja Lidija Andrejevna Glonina (synt. 1940). Yhtyeen kaksi nuorinta toisen polven jäsentä ovat syntyneet 1963. Aiemmin yhtye oli saanut palkintoja folklorekilpailuissa, mutta keväällä 2006 ilmoitettiin, ettei heitä enää kutsuta ikääntymisen takia. Tällä oli suuri vaikutus henkiseen ilmapiiriin kylässä. Ennen usein lauluharjoituksiin kokoontuneista naisista tuntui, ettei heillä ole enää mitään arvoa kylänsä ulkopuolella.

Alun perin Zaovražnyje Karatai oli venäläinen kylä, mutta 1954 Mensitovon (Mensitovan tai Mel'sitovon) karatailaiset asukkaat muuttivat sinne, koska heidän oma kylänsä jäi patoaltaan alle. Vuonna 1869 Mensitovin järven rannalla sijainneessa Mensitovossa oli 276 asukasta (ja määrä oli sama myös vuonna 1875). Vuosikymmen aikaisemmin taloja oli ollut 57 (Vetšeslav 1875: 362-363; Belitser 1960: 229). Vuonna 1908 siellä asui 207 miestä ja 214 naista (Filippov 1913: 355). Jonkin kansanuskomuksen mukaan se oli vanhin kolmesta karatailaiskylästä ja muiden asukkaat olivat sieltä lähtöisin (Paasonen 1903a: 13-14). Vielä 1950-luvulla vanhat mensitovolaiset asuivat Zaovražnyje Karataissa omalla kadullaan ja muodostivat neljänneksen kylän asukkaista. Nykyään siellä asuu enimmäkseen muualta tulleita uudisasukkaita. Vanhoista Mensitovon karataista on jäljellä viitisen henkeä. Nämä sanoivat pitävänsä itseään jo venäläisinä ja suhtautuivat hyvin epäluuloisesti ulkopuolisiin kyselijöihin. He arvelivat vielä noin 15 mensitovolaisen asuvan muualla. Aiemmin kylässä oli vain 45 taloa, mutta niiden luku on kasvanut kesämökkien myötä. Leipomo paloi 2003, eikä uutta ole rakennettu. Mitään palveluita ei ole, lähin kauppa on parin kilometrin päässä ylämäessä.

Kolmas kylä Šeršalan (Šaršalan, Šalan, Malyje Karatai tai omakielisesti Paasosen aikaan T'š́rš́alan) on nykyään täysin hylätty. Nimen on selitetty tulevan tataarin sanoista čâršš̀ 'kuusi' ja alan 'niitty' (Belitser 1960: 230). Vuonna 1859 siellä oli 92 taloa. Vähän myöhemmin siellä asui tilastojen mukaan 555 mordvalaista ja 120 venäläistä (Vetšeslav 1875: 362-363; Paasonen 1903a: 13-14). Venäläiset tulivat kylään vähän mordvalaisten jälkeen, 1600-luvun lopulla. 1950-luvulla kylän toista päätä nimitettiin asukkaidensa mukaan venäläiseksi pääksi ja toista mordvalaiseksi pääksi tai kaukaiseksi pääksi (Belitser 1960: 229-231). En löytänyt Šeršalania enää yhdestäkään kartasta, eivätkä useimmat paikalliset asukkaat tuntuneet tietävän sen sijaintipaikkaa Kljarjajoen (Klärä) varrella. Pitkin peltoja ja pensaikkoa useita tunteja kestäneen ajelun jälkeen sain suostuteltua erään läheisen maatilan työntekijän oppaaksi, ja hän kykeni lopulta näyttämään ränsistyneitä taloja joen rinteessä, koska oli itse käynyt siellä useasti parikymmentä vuotta sitten. Tyhjentymisen syitä ja ajankohtaa ei hänkään kyennyt sanomaan. Kaikki kylään johtavat tiet olivat kasvaneet umpeen. Vain muutamat renkaanjäljet heinikossa osoittivat, että jotkut - luultavasti entiset asukkaat - kävivät kylässä rentoutumassa ja juopottelemassa.

9 Tämä kirjoitusasu perustuu Paasosen $(1901,1953)$ julkaisuihin. 


\section{I.3. Karataiden merkitys ja tulevaisuus}

Kylien siirtämiset, niiden perspektiivittömiksi julistaminen ja luontoa muokkaavat suuret rakennushankkeet voivat tehdä peruuttamatonta tuhoa pienten etnosten keskuudessa. On sinänsä hämmästyttävää, että karataiden mordvalainen identiteetti on voinut säilyä näin pitkään kielen kadottua jo sukupolvia sitten. Pienet impulssit lähistön ersäläis- ja mokšalaiskylistä ovat varmaan olleet melko ratkaisevia ja tuoneet nyt jo hävinneeseen pukuperinteeseen mielenkiintoisia lisiä. On jonkin verran epäselvää, mitä ortodoksinen usko on merkinnyt heidän asemaansa muihin tataareihin nähden. Tilastojen mukaan kristittyjä oli Kazanin kuvernementin puolesta miljoonasta tataarista kymmenesosa (Vetšeslav 1875: 375-376). Vallankumouksen jälkeen uskonnon merkitys väheni ja sen harjoittamista ainakin julkisesti oli syytä karttaa. Tällä hetkellä koko Venäjällä kulutetaan suuria summia uskonnollisten muistomerkkien entistämiseen. Karatailla vain sellaisia ei enää ole jäljellä.

Karataiden 1900-luvun perinnettä on ainakin heidän lukumääräänsä nähden runsaasti dokumentoituna eri arkistoissa. Tataarilaiset tutkijat tallensivat heidän folklore-esityksiään vuonna 1960, ja aineisto on Venäjän tiedeakatemian Kazanin haaraosaston hallussa. Uudella matkalla 10 vuotta myöhemmin oli mukana kaksi unkarilaista, etnomusikologi László Vikár ja lingvisti Gábor Bereczki, jotka ikuistivat levylleen ${ }^{10}$ kolme näytettä karataiden musiikkiperinteestä, itkun ja kaksi laulua. Ersäläisen musiikkitieteilijän Vladimir Ivanovitš Romaškinin ${ }^{11}$ (1951-2002) mukaan karataiden musiikki edustaa kahden kulttuurin symbioosia. Yhteys ersäläisiin ja mokšalaisiin kuolinitkuihin on selvä. Sen jälkeen ovat yksittäiset tutkijat tai tutkimusryhmät Kazanista ja Saranskista käyneet silloin tällöin karataiden luona ja joitakin opinnäytteitä on tehty ja artikkeleita julkaistu. Parisenkymmentä vuotta sitten Mordvan tutkimusinstituutin varastoissa oli jo 350 laulua ja itkua variantteineen (Romaškin 1986: 46, 50). Karataiden elämästä on Kazanin TV käynyt muutama vuosi sitten tekemässä videofilmin. Toinen, aivan uusi filmi heistä ja heidän perinteistään esitettiin juuri äskettäin Venäjän televisiossa.

Rikkaan Tatarstanin karataiden säilyminen on enää yhden alle 100-henkisen kylän varassa. Mordovskije Karatain kohtalo näyttää sinetöidyltä asukkaiden ikääntyessä ja talojen autioituessa. Väestöpohja on kyllä jo kokenut melkoisen muutoksen ja lapset venäläistyneet. Varsinaisia puhtaita karataita ei tässäkään kylässä ole enää monta, niin paljon on perheisiin tullut venäläisiä ja muiden alueiden tataareja. Sinänsä kielen elvyttäminen nuoremman väen puhekieleksi olisi mahdollisuuksien rajoissa, ja kenties siihen löytyisi haluakin, sillä kielellinen identiteetti tuntui kylän naisista tärkeältä. Jollei kylän kehittämiseen kiireesti löydy varoja eikä lapsiperheiden kipeästi kaipaamia kulkuyhteyksiä saada parannettua, on tämä erikoinen, tutkijoille paljon

10 Folk Music of Finno-Ugrian and Turkic Peoples - Finnugor és török népek zenéje. Hungaroton Lpx 18087-89. Hungarian Academy of Sciences, Institute of Musicology, 1984. Levyn aineisto on kerätty vuosina 1966-1977.

11 Kansainvälisesti tunnetun miesten folkloreyhtyeen Tooraman (alkuperäiseltä nimeltään Торама) perustaja ja johtaja vuodesta 1990. 
päänvaivaa aiheuttanut pieni kansanryhmä pian historiaa ja kylän nimikin pyyhkiytyy pois kartoista. Sen arvo pitäisi ymmärtää muutenkin kuin vain eksoottisena tutkimuskohteena. Arkistoaineiston pohjalta pystytään kyllä vielä pitkään tuottamaan uutta tietoa karataista, vaikka heidän puhumansa tataarin murre olisikin jo siirtynyt kuolleiden kielten joukkoon.

\section{Saratovin alueen mordvalaiset}

\section{I. Tutkimushistoria}

Matkan toisen osuuden tein Saratovin alueelle seuratakseni venäläisen akateemikon Aleksei Aleksandrovitš Šahmatovin (1864-1920) jalanjälkiä. Vuosina 1905, 1906 ja $1909^{12}$ hän keräsi folkloremateriaalia kahdesta ersäläiskylästä Saratovin kihlakunnasta (Šahmatov 1910: I, III, VI). Samalla hän perehtyi paikallisten sivistyneistön jäsenten kanssa kummankin murteen kielioppiin ja niiden erikoispiirteisiin. Sekä Paasonen että Jevsevjev olivat hänen kanssaan kirjeenvaihdossa ja antoivat hänen käyttöönsä omia tutkimuksiaan, osittain heillä kolmella oli jopa yhteisiä avustajia kylissä. Kiinnostus mordvalaisiin oli Šahmatovilla lapsuuden perua. Vanhempiensa kuoltua (vuosina 1870 ja 1871) Aleksei-poika vietti lapsuutensa setänsä vanhassa kartanossa Gubarevkassa lähellä Saratovin kaupunkia (Vinogradov 1922: 6; Astahova 1963: 148). Oman kertomansa mukaan poika luki 12-vuotiaana Pavel Ivanovitš Melnikovin ${ }^{13}$ (1818-1883) salanimellä Andrei Petšorski laatiman kuvauksen Очерки мордвы, ensimmäisiä mordvalaisten etnografiaa käsitteleviä monografioita, joka oli julkaistu vuonna 1867 Русский вестникъ -lehdessä.

Matkojensa jälkeen Šahmatov julkaisi Pietarissa vuonna 1910 kuuluisan 848sivuisen monografian Мордовскій этнографическій сборникъ, ensimmäisen kattavan esityksen eteläisistä mordvalaisista. Kaikesta päätellen hänen välinsä tutkittaviin olivat lämpimät; kokoelman 67. laulu Arčiloŭ kertoo tietyn kaavan mukaan hänen romanssistaan Suhoi Karabulakin Nataša-neitosen kanssa (Šahmatov 1910: 570-572). Hän oli nopea kirjoittaja, joka tiettävästi jo vuonna 1905 oli painattanut suppean muutaman kappaleen koevedoksen nimellä Материалы по мордовскому языку и словесности (Dulitšenko 1997: 45 viittaa Bubrihin todistukseen vuodelta 1947 Šahmatovin arkiston sisällöstä). Jäipä mordvalaismateriaalia vielä ylikin odottamaan myöhempää julkaisua (Šahmatov 1910: III-IV). ${ }^{14}$ Kokoelma on arvioitu varsin korkealle, vaikka korjattavaakin löytyy: mm. arkielämää ei käsitellä lainkaan eikä informanteista ole mitään biografisia tietoja (Paasonen 1913; Markelov 1922: 57; Astahova 1963: 147-151). M. A. Castrénin satavuotismuistokirjaan Šahmatov lähetti

\footnotetext{
12 Viimeinen käynti puuttuu tärkeimmistä häneen viittaavista lähteistä; se käy kuitenkin selvästi ilmi, kun lukee kirjan koko esipuheen. Matjuškin (1964: 82) lisää käyntiajankohdaksi vielä vuoden 1907.

13 Venäläinen aatelinen kirjailija ja tiedemies, todellinen valtioneuvos, julkaissut useita etnografisia tutkimuksia eri alueiden mordvalaisista ja romaaneja Volgan vanhauskoisista (Mokšin 2001c). Hänen kirjoistaan julkaistaan edelleen uusia tutkimuksia.

14 Ilmeisesti aineisto odottaa edelleen työstäjäänsä ja julkaisijaansa.
} 
vielä tyrmässä istuneen avustajansa muistiinmerkitsemän pienen kertomuksen mordvalaisten alkuperästä (Šahmatov 1913-1918). Hän ehti vuodesta 1884 lähtien kerätä mittavan folkloristisen aineiston venäjän eri murteista ja valkovenäjästä. Vaikka omat julkaisut aiheesta jäivät tekemättä, hän käytti kyllä aineistoaan omissa kielitieteellisissä tutkimuksissaan ja antoi muidenkin niitä hyödyntää. Tästä syystä myöhempi tutkimus ei ole osannut antaa hänelle kylliksi arvoa folkloristina ja etnografina (Astahova 1963: 133-134).

Šahmatovin monografiaan sisältyi myös vanhan hannoverilaisen aatelissuvun jäsenen historioitsija, etnografi ja tuomari Aleksandr Nikolajevitš Minhin (Münch; 1833-1912) kirjoittama 40-sivuinen historiallis-maantieteellinen kuvaus Orkinosta. Vuosina 1861-1888 Minh keräsi kansantapoja, uskomuksia Saratovin alueelta, julkaisi ne Pietarissa (Minh 1890) ja sai Venäjän maantieteellisen seuran hopeamitalin töistään 1890 (Mokšin 1993: 115; Jurtšonkov 2001, 2007; WDN).

Мордовскій этнографическій сборникъ on tuottanut myös jatkotutkimuksia. Juutalainen Berliinin yliopiston yleisen kielitieteen professori Ernst Lewy (18811966) julkaisi Irlantiin paettuaan Šahmatovin merkintätavan pohjalta kaksikin ersämordvan painotusta koskevaa tutkimusta (Lewy 1937, 1961).

Fennougristiikan alkuvaiheissa Venäjällä Šahmatovin panos oli merkittävä, ja hänet kutsuttiin Suomalais-Ugrilaisen Seuran kunniajäseneksi 1910. Seuraavana vuonna hän vaati tämän tieteenalan edustusta Venäjän tiedeakatemiaan ja oppituolia yliopistoihin. Vuosina 1918-1920 hän osallistui fennougristiikan organisoimiseen syksyllä 1909 avattuun Saratovin valtionyliopistoon (Matjuškin 1964: 83; Mokšin 1993: 94-102, 110-115). Kaiketi poliittisista suhdanteista johtuen varsinaista fennougristiikkaa tuskin koskaan oli yliopiston opetusohjelmassa, tai ainakin venäläisten kirjoittamat lähteet vaikenevat siitä. Sen verran kerrotaan, että 1920-luvun lopulla yliopiston pedagogisessa tiedekunnassa oli kuusi osastoa, joukossa mordvan kieli ja kulttuuri, ja että Saranskiin perustettiin Mordvan pedagoginen instituutti Saratovin yliopiston avustuksella (SU 1959: 27, 38). Mordvalaislähde paljastaa hieman enemmän: venäläisen aatelissukuisen historioitsijan Aleksandr Aleksandrovitš Geraklitovin (1868-1933) aloitteesta avattiin vuonna 1925 Saratovin yliopistoon mordvan kielen ja kulttuurin osasto, jonka opiskelijavalintoihin hän itse osallistui. Geraklitov luennoi heille paleografiaa ja mordvan kansan historiaa (Žiganov 2001, 2007). Samana vuonna yliopiston yhteydessä aloitti toimintansa myös Etelä-Volgan alueen kotiseudun tutkimuksen instituutti ${ }^{15}$, jonka ensimmäisessä julkaisussa oli Geraklitovin artikkeli Saratovin seudun mordvalaisten asutushistoriasta. Pieni tutkimus keskittyy sen silloisen pohjoisosan - nykyisen Penzan alueen ja Mordvan tasavallan - historiaan, kuten 1600-luvun kyliä esittelevästä kartasta ilmenee (Geraklitov 1926; Kalima 1927: 120).

\footnotetext{
15 Instituutissa oli kolme osastoa: luonnontieteellis-historiallinen, taloustieteellinen ja kulttuurishistoriallinen. 1920-luvun alussa oli Saratovin yliopistoon perustettu arkeologian laitos, josta tehtiin 1922 arkeologian instituutti, joka puolestaan laajennettiin em. kotiseudun tutkimuksen instituutiksi. 1930-luvun jälkipuoliskon puhdistukset vaikuttivat erittäin tuhoisasti instituutin toimintaan. (Janin \& Prjahin 2000.)
} 
Šahmatovia ei löydy Saratovin yliopiston professoriluettelosta, mutta sen sijaan mainitaan hänen lahjoittaneen (kaiketi 1910) teoksensa sen tieteelliselle kirjastolle (SU 1959: 249). Myöskään ei kerrota muista kuin hänen venäjän kieleen liittyvistä ansioistaan. Kielitieteestä kirjoitetaan varsin pitkästi, mutta täysin venäjään keskittyen. Venäjän (kirjallisuuden) professorin Boris M. Sokolovin kohdalta (professorina 1919-1923) löytyy varovainen maininta hänen jatkaneen Saratovin alueen etnografian ja folkloren tutkimista Šahmatovin, Kostomarovin ${ }^{16}$ ja Minhin tutkimusten pohjalta. Yllättäen ensimmäisenä talvenaan Sokolov pidätettiin ja opetus keskeytyi neljäksi kuukaudeksi (Otšet 1922: 34). Tuolloin Saratovissa vallitsi kyllä suuri into tutkia lähistön mordvalaisia, varsinkin kun oli huomattu näiden venäläistyminen (Ljubomirov 1922: 247-248). Sokolov organisoi myös kenttätyömatkoja, joihin osallistuivat laajat piirit eri kansallisuuksista koostuvista tieteentekijöistä ja opiskelijoista aina kulttuurihenkilöihin (SU 1959: 118).

Näiden matkojen tuloksena lähellä Petrovskin kaupunkia syntynyt ersäläinen monipuolinen kulttuurintutkija ja museomies Mihail Timofejevitš Markelov (18991937) laati kansatieteellisen kuvauksen jo 23 -vuotiaana. Siinä hän otti kriittisen kannan kansansivistykseen valittaen koulujen edistävän mordvalaisten venäläistymistä omien vähemmistökansoista nousseiden opettajavoimien puuttuessa. Tuolloin kansallisia alakouluja oli Petrovskin kihlakunnassa kolme (Markelov 1922: 66). Muutaman vuoden kuluttua Markelov itse johti tutkimusretkiä mordvalaisalueille, ja näillä matkoilla vain hieman nuorempi Belitser aloitteli uraansa (Mokšin 1993: 161-162). Markelovin opiskelutoveri Pavel Dmitrijevitš Stepanov (1898-1974), myöhemmin ennen kaikkea arkeologina tunnettu, laati ensimmäiset tutkimuksensa Saratovin mordvalaisten etnografiasta (Stepanov 1928, 1930; Mokšin 1993: 155-158). Saratovin yliopiston tekemät tutkimukset jatkuvat edelleen, mordvalaiskylissä liikkuu silloin tällöin opiskelijaryhmiä kansanperinteeseen perehtymässä.

\subsection{Orkinon historiaa ja nykypäivää}

Tämä eteläisin Venäjän mordvalaisryhmä on kooltaan 16500 henkeä, ja se muodostaa vain $2 \%$ koko Saratovin alueen väestöstä (FUW 2004: 8-9). Suurin osa heistä asuu alueen pohjoisosissa melko lähellä Penzan alueen rajaa, jossa on suuri mordvalaiskylien keskittymä Petrovskin rajonissa. Edelleenkin sieltä näyttää löytyvän 13 kaikkiaan 28 Saratovin alueen mordvalaiskylästä (Feoktistov \& Saarinen 2005: 405-406). Saratovin alueen venäläistyminen on tilastojen valossa voimakasta.

Ensimmäinen kohteeni oli hyvin tunnettu kylä nimeltään Orkino (tai Roždestvenskoje) Petrovskin rajonissa. Se on perustettu vuonna 1712, ja sen asukkaat olivat luontouskoisia 1700-luvun puoliväliin saakka, jolloin heidät kastettiin väkivalloin. Yleinen vuosina 1745-1747 toteutettu väestönlaskenta kertoo Orkinon ersäläisten asukkaiden tulleen Penzan ujestin Matšimin ja Sadomin kylistä. Tuolloin 16 Nikolai Ivanovitš Kostomarov (1817-1885), venäläinen aatelinen historioitsija, etnografi ja kirjailija
(Jeferina 1997). 
tilastoihin merkittiin 110 miestä. (Minh 1910: 692). Paikalliset kutsuvat kyläänsä nimellä Kutšugury, joka on myös heidän kansanperinneyhtyeensä nimi. Seuraavat tiedot kylän asujainten määrästä ovat puolentoista vuosisadan takaa: eri lähteet 1850luvulta ilmoittavat sen olleen jonkin verran vajaat 3000 henkeä, vuosina 1882-1883 n. 4000, vuonna 1897 n. 5500 ja vuonna 1911 yli 7000, jotka tosin oli kaikki merkitty virheellisesti venäläisiksi, kuten tutkija huomauttaa (Stepanov 1930: 35, 44). Joka tapauksessa luotettavampi tieto 1900-luvun ensimmäiseltä vuosikymmeneltä kertoo Orkinon väkiluvun olleen hieman vajaat 6000 henkeä ja mordvalaisten joukossa olleen vain kourallinen venäläisiä (Šahmatov 1910: III).

Orkinossa on tätä nykyä vain n. 850 asukasta. Kylän koulu on Saratovin alueen vanhimpia maalaiskouluja, perustettu vuonna 1840. Ensi vuosikymmeninä se toimi vain ajoittain. Nyt siinä on 40 oppilasta, 11 luokkaa ja 13 opettajaa. Ersän kieltä ei opeteta, vaikka sitä puhutaankin melkein kaikkialla pitkin kylänraittia, eivätkä opettajat ainakaan tienneet sitä koskaan koulussaan opetetun. Muista lähteistä tiedetään, että vallankumouksen jälkeen Saratovin kuvernementissa, joka oli tuolloin suurempi kuin nykyinen Saratovin alue, oli kouluissa opetusta jonkin aikaa kansallisilla kielillä (Stepanov 1928: 1). Demografinen tilanne on tällä haavaa huolestuttava, sillä alle kouluikäisiä lapsia on vain 30-35, heistä lastentarhassa kuusi. Tulevaisuudessa on vaara, että koulu suljetaan tai sen statusta lasketaan, jolloin opetettaisiin vain luokkia 1-8 ja ylempien luokkien oppilaat joutuisivat naapurikylään. Kolhoosien romahdettua kylien työmahdollisuudet ovat vähentyneet, mikä heijastuu sosiaalisina ongelmina. Koulutyötä vaikeuttaa, että suuri osa lapsista tulee rikkinäisistä ja alkoholiongelmaisista perheistä.

Orkinon kylä oli minulle jo tuttu kesältä 2000, jolloin päädyin sinne luettuani kollegani löytämän pitkän mairittelevan sanomalehtiartikkelin. Orkinossa kehuttiin ersäläisten elvyttävän äidinkieltään pitämällä koululaisille ersän kielen oppitunteja ja kokoamalla Ersäläiseen kulttuurikeskukseen museoesineitä ja kansanpukuja. Todellisuus oli perin toisenlainen. Hyvin nuori opettaja ei osannut montakaan ersän kielen sanaa ja tunnustikin oikeastaan opettavansa kotiseutuoppia venäjäksi. Neitonen oli juuri vaihtanut työpaikkaa tultuaan nimitetyksi kylän hallintojohtajaksi. Lehtiartikkeli oli tuonut hänelle kovasti lisäpisteitä valittaessa edellisen kerran Petrovskin rajonin vuoden opettajaa, ja hän olikin sijoittunut kilpailussa kärkipäähän. Silloinen koulun johtaja puhui ersää vain suurin ponnistuksin, vaikka olikin paikkakuntalaisia.

Orkinon ersäläinen kulttuurikeskus on iso huone, jonne on kerätty sekalaisia maataloustavaroita. Mainostetut ersäläisvaatteet on saatu lahjoituksina satunnaisilta vierailta, ja ne ovat ns. esiintymispukuja. Kulttuurikeskuksen johtaja on kylän maataloustoiminnan ja folkloreyhtyeen johtaja sekä harmonikan soittaja. Folkloreryhmän kymmenkunta naista esittivät ersäläisiä lauluja oikein taidokkaasti, ukrainalaiset ja venäläiset laulut olivat myös edustettuina ohjelmistossa. Kutšugury on ollut tunnettu jo vuodesta 1960, ja sitä kutsutaan usein kauaskin esiintymään etenkin mordvalaisten omille folklorejuhlille nimikkotasavaltaan ja diasporaan.

Matkani aikana syksyllä 2006 kylän johto asettui vastahankaan eikä pyytämäni kuljetus naapurikyliin lupauksista huolimatta järjestynyt - edes maksua vastaan. Sato 
oli juuri saatu korjattua ennätysajassa, mikä oli ollut edellytyksenä auton saamiselle. Sinä vuonna Orkino oli Petrovskin rajonin nopein kylä, mutta se ei paljon lohduttanut, sillä kukaan autonomistajista ei uskaltanut ajaa minua ja kollegaani minnekään kaikki vain sanoivat, että ensin on saatava lupa korkeammalta taholta. Sään muututtua sateiseksi ja peltojen liejuisiksi eivät pitkät kävelymatkat tuntuneet houkuttelevilta, joten muutamien pienten naapurikylien mahdollinen ersän puhumistilanne jäi vielä selvittämättä. Harmikseni tältä osin suunnittelemani tutkimusohjelma jäi vajaaksi. Orkinolaisilta sain muista lähistön ersäläistaajamista aika ristiriitaisia tietoja.

\subsection{Suhoi Kar(a)bulakin historia ja nykypäivä}

Toinen matkakohteeni oli melko tuntematon rautatiepysäkki Suhoi Karabulak (tai Karbulak) Bazarnokarabulakin tataarilaisessa rajonissa. Samassa rajonissa on väestönlaskentatilastojen mukaan vain yksi toinen mordvalaiskylä: Rjazaikino (Feoktistov \& Saarinen 2005: 405-406). Matka Suhoi Karabulakiin kesti Saratovista kaksi tuntia sähköjunalla. Paikallinen ersäläinen nimi kylälle on Arčilov tai Arčilovvel'e. Jossakin vaiheessa sillä oli myös nimi Belogorskij vel'e. Koulun historiataulun mukaan Suhoi Karabulak muodostui 1700-luvun ensimmäisellä neljänneksellä. Sen väkiluku ei 100 vuotta sitten ylittänyt 3000:ta henkeä (Šahmatov 1910: III), mikä saattaa kyllä olla liian suuri arvio muiden tilastojen valossa - kuten vuoden 1911 virallisten väestötilastojen n. 1750 henkeä antaa aiheen epäillä (Stepanov 1930: 44). Joitakin varhaisempiakin tietoja asukasmääristä löytyy: 1850-luvulta eri lähteistä n. 1100 henkeä, v. 1882-1883 n. 1500 henkeä, v. 18971830 henkeä (Stepanov 1930: 44).

Vuonna 2006 siellä on enää jäljellä vain n. 940 pysyvää asukasta sekä joitakin opiskelijoita, joita ei kuitenkaan lasketa mukaan päälukuun. Koulussa oli 71 oppilasta, 11 luokkaa ja n. 15 opettajaa. Vieraana kielenä oli hieman yllättäen ranska! Koulussa oli vapaaehtoista ersäläisperinteiden ja folkloren opetusta, koska vanhemmat ja opettajat pitivät tärkeänä, että lapset oppivat tuntemaan juurensa. Pääsin seuraamaan sekä 2. että 5. luokan vapaaehtoisia ersäntunteja, joilla oppilaat pantiin laulamaan minulle. Tämä opetus on suuressa vaarassa, sillä aineenopettaja Ljubov Vasiljevna Molonjonkova, joka itse asiassa on koulutukseltaan alaluokkien opettaja, on jäämässä eläkkeelle. Erityistä kielitieteellistä valmennusta tehtäväänsä hänellä ei ole, mitä hän itse kovasti valitteli. Syksyllä 2006 lasten päiväkodissa oli 24 lasta ja heitä kaitsemassa kaksi kasvattajaa, johtaja ja ruokalan työntekijä. Kaikkiaan kylässä oli 46 alle kouluikäistä. Edellisenä vuonna oli syntynyt poikkeuksellisen iso vuosikerta, 13 lasta. Yleensä lapset ovat aivan normaaleista perheistä; suuria sosiaalisia ongelmia ei kerrottu olevan, mikä johtuu kylän poikkeuksellisen edullisesta sijainnista ja sen asukkaiden hyvästä sosioekonomisesta tilanteesta. Aseman luona on kauppa, keskustassa kolme, mikä merkitsee, että asukkailla on ostovoimaa. Rautatien lisäksi myös voimala työllistää monia kyläläisiä. Äskettäin sinne on asettunut entisistä Neuvostoliiton Keski-Aasian tasavalloista palanneita venäläisiä. Saratovilaisetkin ovat hyvien liikenneyhteyksien takia alkaneet hankkia kesämökkejä kylän tyhjentyneistä taloista, mikä merkitsee vääjäämätöntä ersän kielen katoamista lähivuosikymmeninä. 
Vain Suhoi Karabulakin vanhempi väestönosa puhuu enää jossain määrin ersää. Kylän klubilla kokoontuu aktiivinen folkloreyhtye, joka koostuu yhdestä perheestä. Sen ytimenä on perinteentaitaja Olga Aleksandrovna Karpova (synt. 1930) lapsineen, vanhempi tytär on klubin johtaja Tatjana Ivanovna Fedjaikina (synt. 1958), nuorempi tytär Irina Ivanovna Loginova (synt. 1969) on huolehtinut jälkikasvusta kolmen lapsen verran ja heidän puolikuuro veljensä Sergei Ivanovitš Karpov (synt. 1952) soittaa harmonikkaa. Rouva Karpova kutsutaan silloin tällöin juhlien vetonaulaksi myös kertomaan satuja ersäksi.

\section{Diasporan mordvalaisten ja heidän kielensä kohtalo}

Olen tehnyt kenttätöitä mordvalaisten parissa vuodesta 1990 lähtien. Aluksi olojen vapautuminen piristi kyläelämää. Vaikka palkkoja ei maksettu ajoissa tai täysimääräisinä ja monet perheet elää kituuttivat isoäidin eläkkeellä, oli silti toivoa paremmasta. Kulutustavaroita alkoi saada jonottamatta, eivätkä ne olleet hirvittävän kalliita. Jääkaappeja ilmestyi köyhiinkin talouksiin. Pikku hiljaa kylissä kuitenkin huomattiin, että elintason nousu ei ulotu Keski-Venäjän maaseudulle. Valtaosa kanavoituu suurkaupunkien uusrikkaille, jotain tihkuu provinssikaupunkeihin, mutta kylät ovat pitkälti jääneet oman onnensa nojaan. Karjan pääluku on yleensä pudonnut murto-osaan parinkymmenen vuoden takaisista määristä, autioita navettoja ja hylättyjä traktoreita näkee kaikkialla, niin Orkinossakin. Monet rakennuskohteet ovat jääneet kesken rahojen loputtua. Yleinen toivottomuus on vallalla maaseudulla viljavasta maaperästä huolimatta.

Saratovin alueella tilanne vaihtelee. Samankokoisista kylistä Orkino on liikenteellisesti eristyneempi, ja koska sen talous on pääasiassa maanviljelyn varassa, muita työmahdollisuuksia on niukalti. Sen vanhempi väki osaa vielä erinomaisesti ersää. Lähistöllä on myös ollut useita pieniä ersäläiskyliä, jotka lienevät nyt enemmän tai vähemmän venäläistyneitä. Suhoi Karabulakiin taas on helppo päästä rautateitse, elintaso on siellä selvästi korkeampi ja niinpä sinne riittää nuoriakin muuttajia. Kylän vanhemman väen ersän taito on jo ruosteessa käytön puutteessa. Ilmeisesti siellä vieraskieliset tulijat ovat kuitenkin saaneet mordvalaisyhteisön ymmärtämään paremmin oman kulttuurinsa arvon ja kohentaneet siten myös kansallista identiteettiä. Tärkeää olisi myös saada joka kylään joku arvostettu voimahahmo, joka puhuisi pienen äidinkielen ja kulttuurin säilyttämisen puolesta vaikeissakin taloudellisissa oloissa. Diasporassa ersän ja mokšan kielen asema on selvästi huonompi kuin nimikkotasavallassa, ja se näkyy etenkin koulujen opetustarjonnassa.

Vähemmistöjen kansallisen äidinkielen käyttöalue ei näytä laajentuvan perheen ja kyläyhteisön ulkopuolelle. Ainakaan vähemmistökielen osaamisesta ei makseta palkanlisää eikä sen taitoa vaadita missään, joitakin huonosti palkattuja ja aliarvostettuja opetus- ja kulttuuritehtäviä lukuun ottamatta, ja niitäkin on vuosi vuodelta vähemmän. Silti vähemmistöjen asema voi vaihdella yllättävästi riippuen paljolti paikallishallinnon asenteesta. Orkinon tilanne on hyvin tyypillinen: vähemmistökielten todelliselle opetukselle ei opetushallinnossa panna paljon painoa 
eikä sitä pidetä tarpeellisena. Varsinkaan mordvalaisten diasporassa päättäjät eivät pidä vähemmistökielten opettamista enää koulujen tehtävänä. Viime vuosina lasten päiväkoteja on suljettu ja kansallisten kielten opetus kouluissa tehty marginaaliseksi. Sen sijaan tataaria opetetaan monen viikkotunnin voimin koko kouluajan laajalti Tatarstanin ulkopuolella diasporassakin, lapset käyvät lauantaisin koraanikoulua eikä omaa kulttuuria juurikaan väheksytä. Tataarikylässä myös muiden kansallisuuksien lapset osallistuvat tataarin kielen ja kulttuurin opetukseen. Milloin vastaavaa voitaisiin kertoa mordvalaisista tai muista Venäjän suomalais-ugrilaisista?

\section{Lähteet}

Ahlqvist, Aug. 1858: Neljäs matkakertomus Suomen Yliopiston ylistettävälle Konsistoriolle. - Suomi 1857: 261-266. Helsingfors: Finska Litteratur-Sällskapets tryckeri.

Ahlquist, August 1861: Versuch einer mokscha-mordwinischen Grammatik nebst Texten und Wörterverzeichniss. (Forschungen auf dem Gebiete der Ural-Altaischen Sprachen 1.) St. Petersburg: die Kaiserliche Akademie der Wissenschaften.

Arslanov 1965 = Арсланов, Л. Ш.: Некоторые лексические особенности говора мордвыкаратаев. - Этногенез мордовского народа. (Материалы научной сессии. 8-10 декабря 1964 года.) Саранск: Морд. кн. изд. 396-401.

Arslanov 1991a= Арсланов, Л. Ш.: К вопросу о изучении говора и истории формирования мордвы-каратаев. - Д. Б. Рамазанова (toim.), Мордва-каратаи: язык и фольклор. Казань: Институт языка, литературы и истории им. Г. Ибрагимова. 3-9.

Arslanov 1991b = Арсланов, Л. Ш.: Особенности говора мордвы-каратаев. - Д. Б. Рамазанова (toim.), Мордва-каратаи: язык и фольклор. Казань: Институт языка, литературы и истории им. Г. Ибрагимова. 10-38.

Arslanov 2000 = Арсланов, Л. Ш.: Еще раз о мордва-каратаях. - Финно-угристика 4. Саранск: Морд. гос. ун-т. 26-29.

Astahova 1963 = Астахова, А. М.: А. А. Шахматов как фольклорист и этнограф. - Очерки истории русской этнографии, фольклористики и антропологии II. (Труды Института этнографии им. Н. Н. Миклухо-Маклая, нов. сер. 85.) Москва: Изд. АН СССР. 132-155.

Belitser 1960 = Белицер, В. Н.: Мордва-каратаи и их культура. (К вопросу их происхождения.) - Вопросы этнической истории мордовского народа. Труды мордовской этнографической экспедииии I. (Труды Института этнографии им. Н. Н. Миклухо-Маклая, нов. сер. LXIII.) Москва: Изд. АН CCCP. 227-255.

Dokumenty 1940 = Документы и материаль по истории Мордовской АССР. Том II. Саранск: МНИИЯЛИ 1940.

Dulitšenko 1997 = Дуличенко, Александр Д.: К занятиям академика А. А. Шахматова мордовскими языками (в переписке с И. И. Миккола). - Western and eastern contact areas of Uralic languages. (Fenno-Ugristica 21.) Tartu: University of Tartu, Division of Uralic Languages. 47-52.

Feoktistov 1965 = Феоктистов, А. П.: К проблеме мордовско-тюркских языковых контактов. - Этногенез мордовского народа. (Материалы научной сессии. 8-10 декабря 1964 года.) Саранск: Морд. кн. изд. 331-343.

Feoktistov, Aleksandr \& Saarinen, Sirkka 2005: Mokšamordvan murteet. Suomalais-Ugrilaisen Seuran toimituksia 249. Helsinki: Suomalais-Ugrilainen Seura. 
Filippov 1913 = Филиппов, Гурий: Мордва - христиане. Из жизни села «Мордовские Каратаи» и деревни «Менситово» Тетюшского уезда Казанской губернии. (Историко-этнографический очерк.) - Приложение к журналу «Православный собеседник» за декабрь 1913 года. Книга 5-ая. Казань: Центральная типография. $355-365$.

FUW 2004 = The Finno-Ugric world. Statistical handbook. Syktyvkar: Committee for State Statistics of the Republic of Komi. 2004.

Geraklitov 1926 = Гераклитов, А. А.: Саратовская мордва. К истории мордовской колонизации в Саратовском крае. - Известия Краеведческого Института изучения Южно-Волжской Области при Саратовском государственном университете I. Саратов. 135-155 + karttalehti.

Halikov 1965 = Халиков, А. Х.: Мордовские и болгаро-татарские взаимоотношения по данным археологии. - Этногенез мордовского народа. (Материалы научной сессии. 8-10 декабря 1964 года.) Саранск: Морд. кн. изд. 152-167.

Heikel, Axel O. 1899: Mordvalaisten pukuja ja kuoseja. Trachten und Muster der Mordvinen. Suomalais-Ugrilaisen Seuran kansatieteellisiä julkaisuja 1. Helsinki: Suomalais-Ugrilainen Seura.

Inževatov 1987 = Инжеватов, И. К.: Топонимический словарь Мордовской АССР: Названия населенных пунктов. 2-е изд., дополн. и испр. Саранск: Морд. кн. изд.

Janin \& Prjahin $2000=$ Янин, В. Л. \& Пряхин, А. Д.: Археология на исторических факультетах классических университетов Российской Федерации. История, современность, перспективы. - Commentarii de Historia / Исторические записки. Журнал исторического факультета Воронежского государственного университета. [http://www.hist.vsu.ru/cdh/Articles/04-06.htm 20.4.2009.]

Jeferina 1997 = Еферина, Т.: Костомаров Николай Иванович. - История Мордовии 8 лииах. Биографический сборник. Саранск: Типография «Красный Октябрь». 249.

Jevsevjev 1966 = Евсевьев, М. Е.: Мордва Татреспублики. - Нзбранные труды 5. Саранск: Морд. кн. изд. 385-407. [Julkaistu alun perin: Материаль по изучению Татарстана II. Казань 1925.]

Jurtšonkov 2001 = Юрчёнков, В. А.: Минх Александр Николаевич. - Мордовия. Энииклопедия. Саранск: Морд. кн. изд. 398.

Jurtšonkov 2007 = Юрчёнков, В. А.: Минх Александр Николаевич. - Мордовиясь. Энииклопедия кавто томсо. 1-це томось A-M. Саранск: Морд. кн. изд. 485.

Kalima, Jalo 1927: Zur siedlungsgeschichte der mordwinen. - Finnisch-Ugrische Forschungen XVIII: 116-121.

Lepjohin 1771 = Дневныя записки путешествїя доктора и академіи наукъ адъюнкта Ивана Лепехина по разнымъ провинціямъ Россійскаго государства, 1768 и 1769 году. Часть І. Въ Санктпетербургъ при Императорской Академїи Наукъ, 1771 году.

Lewy, Ernst 1937: Zur Betonung des Erzämordwinischen im Satze. - Finnisch-Ugrische Forschungen XXIV: 232-245.

Lewy, Ernst 1961: Zur Betonung des Erdzja-Mordwinischen von Orkino. Sitzungsberichte der Deutschen Akademie der Wissenschaften zu Berlin. Klasse für Sprachen, Literatur und Kunst. Jg. 1961: 1. Berlin: Akademie Verlag.

Ljubomirov 1922 = Любомиров, П. Г.: О важности изучения мордвы. - Саратовский этнографический сборник I. Саратов: Издание мордовского под'отдела Гувернского отдела по делам национальностей при Саратовском Губисполкоме. 239-249. 
Markelov 1922 = Маркелов, М. Г.: Саратовская мордва (этнографические материалы). - Саратовский этнографический сборник I. Саратов: Издание мордовского под'отдела Гувернского отдела по делам национальностей при Саратовском Губисполкоме. 51-238.

Matjuškin 1964 = Матюшкин, П.: А. А. Шахматов академиксь и мордовскяй кяленьвалонь наукась. - Мокша 1964: 3: 81-83.

Melnikov, P. 1867 [1981] = Мельников, П. И. (Андрей Печерский): Очерки мордвы. Саранск: Морд. кн. изд. [Julkaistu alun perin v. 1867 Русский вестникъ -lehden numeroissa 6, 9 \& 10. Julkaistu mуös v. 1897-1898 ja 1909 teoksessa Польное собрание сочинений П. И. Мельникова (Андрея Печерского). 2. изд., том 7.]

Melnikov, S. 1859 = Акты историческіе и юридическіе и древнія ичарскія грамоть Казанской и других соспдственных губерній. Томъ I. Казань: изданные иждивеніемъ Казанскаго Губернскаго Статистическаго Комитета.

Melnikov, S. 1862 = Мельников, С. Г.: Поминки или дмитріевская суббота, въ селе Каратаяхъ, Тетюшскаго уъзда. - Казанскія губернскія въдомости. Часть неоффииіальная 9, 5 марта 1862 года.

Minh 1890 = Народные обычаи, обряды, суевърія и предразсудки крестьянъ Саратовской губерніи. Собраны въ 1861-1888 годахъ чл. сотр. А. Н. Минхомъ. - Записки Императорскаго Русскаго Географическаго Общества по Отделенію этнографіи 19: 2. С.-Петербугъ: Императорскаго Русскаго Географическаго Общества. [Julkaistu uudelleen v. 1994 Saratovissa.]

Minh 1910 = Извлеченіе изъ историко-географическаго описанія Озерской волости Саратовскаго уъзда, составленнаго А. Н. Минхомъ. - Мордовскій этнографическій сборникъ, составленъ А. А. Шахматовымъ. С.-Петербургъ: Типографія Императорской Академіи Наукъ. 681-720.

Mokšin 1977 = Мокшин, Н. Ф.: Этническая история мордвы ХІХ-ХХ века. Саранск: Морд. кн. изд.

Mokšin 1989 = Мокшин, Н. Ф.: Мордовский этнос. Саранск: Морд. кн. изд.

Mokšin 1993 = Мокшин, Н. Ф.: Мордва глазами зарубежных и российских путешественников. Саранск: Морд. кн. изд.

Mokšin 2001a = Мокшин, Н. Ф.: Каратайская мордва. - Мордовия. Энциклопедия. Саранск: Морд. кн. изд. 285-286.

Mokšin 2001b = Мокшин, Н. Ф.: Лепёхин Иван Иванович. - Мордовия. Энциклопедия. Саранск: Морд. кн. изд. 355.

Mokšin 2001c = Мокшин, Н. Ф.: Мельников Павел Иванович. - Мордовия. Эничиклопедия. Саранск: Морд. кн. изд. 391.

Mokšin 2007a = Мокшин, Н. Ф.: Каратаень мордва. - Мордовиясь. Энциклопедия кавто томсо. 1-ие томось A-M. Саранск: Морд. кн. изд. 337.

Mokšin 2007b = Мокшин, Н. Ф.: Лепёхин Иван Иванович. - Мордовиясь. Эничиклопедия кавто томсо. 1-ие томось A-M. Саранск: Морд. кн. изд. 433.

Niiranen, Timo 1987: Axel Olai Heikel. Suomalais-ugrilaisen kansatieteen ja arkeologian tutkija. Snellman-instituutin julkaisuja 4. Kuopio: Kustannuskiila Oy.

Otšet 1922 = Очет об этнографических работах по изучению Саратовского края за 1919-1921 г. - Саратовский этнографический сборник I. Саратов: Издание мордовского подотдела Гувернского отдела по делам национальностей при Саратовском Губисполкоме. 1922. 29-49. 
Paasonen, H. 1901: Tatarische Lieder. - Suomalais-Ugrilaisen Seuran Aikakauskirja 19: 2: I-IX.

Paasonen, H. 1903a: Die sogenannten Karataj-mordwinen oder Karatajen. - SuomalaisUgrilaisen Seuran Aikakauskirja 21: 1: 1-51.

Paasonen, H. 1903b: Matkakertomuksia vuosilta 1900-1902. - Suomalais-Ugrilaisen Seuran Aikakauskirja 21: 5: 1-22.

Paasonen, H. 1913: Eine sammlung im gebiet mordwinischer volkskunde. - Finnisch-Ugrische Forschungen (Anzeiger) XIII: 15-26.

Paasonen, H. 1953: Mischärtatarische Volksdichtung. Gesammelt von Heikki Paasonen. Übersetzt und herausgegeben von Eino Karahka. Suomalais-Ugrilaisen Seuran toimituksia 105. Helsinki: Suomalais-Ugrilainen Seura.

Ramazanova 1991 = Рамазанова, Д. Б. (toim.): Мордва-каратаи: язык и фольклор. Казань: Институт языка, литературы и истории им. Г. Ибрагимова.

Ramazanova 2000 = Рамазанова, Д. Б.: Генетические пласти терминов родства мордвыкаратаев. - Материаль II всероссийской научной конференции финно-угроведов. «Финно-угристика на пороге III тысячелетия» (филологические науки) 2-5 февраля 2000 г. Саранск: Морд. гос. ун-т. 258-262.

Romaškin 1986 = Ромашкин, В. И.: О некоторых особенностях традиционного песенного искусства мордвы-каратаев (по материалам экспедиций). - Фольклор в творчестве мордовских писателей $и$ композиторов. (Трулы Науч.-иссл. института ЯЛИЭ 86.) Саранск: Морд. кн. изд. 45-54.

Safargalijev 1965 = Сафаргалиев, М. Г.: Мордовско-татарские отношения. - Этногенез мордовского народа. (Материалы научной сессии. 8-10 декабря 1964 года.) Саранск: Морд. кн. изд. 223-234.

Šahmatov $1910=$ Мордовскій этнографическій сборникъ, составленъ А. А. Шахматовымъ. Въ приложеніи: Описаніе села Оркина Саратовскаго уъзда А. Н. Минха. С.-Петербургъ: Типографія Императорской Академіи Наукъ.

Šahmatov 1913-1918 = Schachmatov, Al.: Eine mordvinische Ueberlieferung über die Herkunft der Mokša und Erźa. - Suomalais-Ugrilaisen Seuran Aikakauskirja 30: 10: 1-4.

SRNG 14 = Словарь русских народных говоров 14. Ленинград: Наука 1978.

Stepanov 1928 = Степанов, П. [Д.]: Саратовская мордва. - Саратовский Гос. Областной музей 1928: 4. Саратов.

Stepanov 1930 = Степанов, П. [Д.]: Районы распространения и численность Саратовской мордвы. - Мордовский сворник. (Ученые записки Саратовского гос. университета, т. VIII, вып. III. Педагогический факультет.) Саратов: Правление Саратовского гос. университета. 33-54.

SU 1959 = Саратовский университет 1909-1959. Саратов: Саратовский гос. университет им. Н. Г. Чернышевского 1959.

Vasmer 1967 = Фасмер, Макс: Этимологический словарь русского языка. Перевод и дополнения О. Н. Трубачева. Том ІІ. Москва: Изд. Прогресс.

WDN = Минх Александр Николаевич. - Die Geschichte der Wolgadeutschen. Энциклопедический словарь. - http://wolgadeutsche.net/lexikon/Muench.htm 20.4.2009.

Vetšeslav 1869 = Отчетъ о дъйствіяхъ Казанскаго губернскаго Статистическаго Комитета. За 1868 годъ. - Труды Казанскаго Губернскаго Статистическаго Комитета, издаваемые подъ редакціею Члена и Секретаря Комитета, Н. Н. Вечеслава. Выпускъ 3-й. 1869 года. В Губернской типографіи. 1-18. 
Vetšeslav 1875 = Естественное приращеніе сельскаго населенія Казанской губерніи по приходамъ, съ обозначеніемъ племеннаго его состава и отношеній между полами. Составиль Членъ и Секретарь Казанскаго Губернскаго Статистическаго Комитета Н. Н. Вечеславъ. Томъ І. Казань: въ Губернской типографіи.

Vinogradov 1922 = Виноградов, В. В.: Алексей Александрович Шахматов. Петербург: Колос.

Zelenejev 1999 = Зеленеев, Ю.: Расселение финно-угров в Волго-Камье в веках. Финно-угроведение 1999: 2-3. Йошкар-Ола: Научный центр финно-угроведения. 23-24.

Žiganov 2001 = Жиганов, М. Ф.: Гераклитов Александр Александрович. - Мордовия. Энииклопедия. Саранск: Морд. кн. изд. 177.

Žiganov 2007 = Жиганов, М. Ф.: Гераклитов Александр Александрович. - Мордовиясь. Энщиклопедия кавто томсо. 1-це томось A-M. Саранск: Морд. кн. изд. 208.

Merja Salo <merja.salo@helsinki.fi>

Suomalais-ugrilainen laitos

PL 25

00014 Helsingin yliopisto 